\title{
Environmental advantages of the reverse logistics: a case study in the batteries collection in Brazil
}

\author{
Geraldo Cardoso de Oliveira Neto ${ }^{\mathrm{a} *}$, Mauro Silva Ruiz ${ }^{\mathrm{b}}$, Auro Jesus Cardoso Correia ${ }^{\mathrm{a}}$, \\ Henrique Manoel Riane Mendes ${ }^{b}$ \\ aUniversidade Nove de Julho, Programa de Pós-graduação em Engenharia de Produção, São Paulo, SP, Brasil \\ bUniversidade Nove de Julho, Programa de Pós-graduação em Gestão Ambiental e Sustentabilidade, São Paulo, SP, Brasil \\ *geraldo.prod@gmail.com
}

\begin{abstract}
Paper aims: Evaluate the environmental advantages of the Reverse Logistics of Portable Batteries carried out by the Brazilian Electrical and Electronics Industry Association (ABINEE).

Originality: The adoption of reverse logistics of batteries contributed with the minimization of environmental impact and stimulated the manufacturers of electronics in the adhesion of sector agreement as well as strengthened the players of reverse chain.
\end{abstract}

Research method: A case study was developed by means of interviews and documental analysis, and for data analysis, the mass balance was carried.

Main findings: 4,304,465 batteries were collected, representing 176,422kg of both solid and chemical wastes, which were disposed properly, reducing the environmental impact.

Implications for theory and practice: The theoretical contribution consists in environmental assessment by means of mass balance of the adoption of reverse logistics of batteries, and the practical contribution consists in stimulating the electronic manufacturers to develop social license among the community, government and players of reverse chain.

Keywords

Electronic waste. Reverse logistics. Environmental advantage.

How to cite this article: Oliveira Neto, G. C., Ruiz, M. S., Correia, A. J. C., \& Mendes, H. M. R. (2018). Environmental advantages of the reverse logistics: a case study in the batteries collection in Brazil. Production, 28, e20170098. https:// doi.org/10.1590/0103-6513.20170098.

Received: Dec. 1, 2017; Accepted: May 3, 2018.

\section{Introduction}

The increase in the consumption of electronic products generates e-waste at its end-of-life, resulting in environmental impact. The management of e-waste, considering the appropriate final disposal, is of interest of the government, shareholders and consumers. Thus, it is important that companies manage e-waste through reverse logistics to comply with the government legislation and minimization of the environmental pollution for the society. Reverse Logistics, according to Rogers \& Tibben-Lembke (1998), is understood as the process of planning, implementing and controlling, including raw materials and discarded products, in which the final destination is the pursuit of return to business cycle. Reverse logistics plans, operates and controls the logistics flow of post-sale and post-consumer products to the business cycle, promoting economic, ecological and legal values (Leite, 2009). The National Solid Waste Policy (NSWP) indicates that the reverse logistics for Waste from Electrical and Electronic Equipment (WEEE) stimulates the return of products at the end-of-life by consumers, distributors, manufacturers and importers for the appropriate disposal for recycling and reuse (Brasil, 2010). Specifically, reverse logistics of batteries stimulates existing collection and recycling initiatives at the national, state and local levels, as provided by the NSWP under Law No. 12,305/2010 (Brasil, 2010) and CONAMA Resolution No. 401/2008 from Brasil (2008). 
The literature from reverse logistics of WEEE indicates the use of mathematical modeling to identify the location of the recyclers and manufacturers of electro-electronic products for the minimization of emissions of $\mathrm{CO}_{2}$ in transport process. The majority of researches used linear programming to plan the logistic disassembly (Walther \& Spengler, 2005), reduce the consumption of fuel (Achillas et al., 2010b) identify the greatest location for installation (Achillas et al., 2012; Aras et al., 2015; Kilic et al., 2015), assess the integration of the formal and informal waste sectors (Li \& Tee, 2012) and identify the absence of rigid federal legislation (Assavapokee \& Wongthatsanekorn, 2012). Other research adopted mathematical simulation to establish RFID technology in WEEE management (Araujo et al., 2015) and used stochastic programming to reduce the pollution in the air (Ayvaz et al., 2015). In addition, other researchers used multicriteria analysis by means of fuzzy, delphi e analytic hierarchy process to assess barriers of RL (Bouzon et al., 2016), while only analytic hierarchy process was used to assess the integration of the formal and informal recyclers (Souza et al., 2016); other study used electre and identified that the WEEE reverse logistics is relevant to meet legislative targets (Achillas et al., 2010a). Futhermore, additional researches adopted ecoeficiency tools (Lucato et al., 2017) to assess the life cycle analysis of the refrigerator recycling (Foelster et al., 2016) and used material intensity factor (Paoli et al., 2013; Oliveira Neto \& Lucato, 2016) for the environmental and economic assessment of recycling and reuse of electronic waste (Oliveira Neto et al., 2017). In addition, other works mentioned only qualitative data regarding the environmental pollution of the inadequate disposal of e-waste in landfills, denoting that it is relevant to implement RL for recycling and reuse of WEEE (Dalrymple et al., 2007) and develop environmental laws to foster the adoption of RL in China (Yang et al., 2008; Lau \& Wang, 2009), because of the lack of control in the formal and informal recyclers of WEEE (Liu et al., 2016). In addition, teaching the concepts of environmental education in schools and companies in Brazil becomes essential (Guarnieri et al., 2016), as it promotes the correct disposal of WEEE in the country (Caiado et al., 2017).

These researches do not consider the mass balance of the polluting components present in the batteries analyzed; moreover, there is not any reference of researches that evaluated the environmental gain by means of mass balance of the polluting components contained in the implementation of reverse logistics of batteries in Brazil; thus, this scenario highlights the gap to be explored in this study. This subject is relevant to be researched because it contributes with the environmental impact reduction and stimulates the manufacturing of electronics in line with in the sectorial agreement. This represents an obligation of adopting reverse logistics for collecting, recycling, reusing and disposing properly the waste, strengthening the players of reverse chain, including the waste management companies, service providers in reverse logistics, formal and informal recyclers and incineration companies. This fact contributes with the Brazilian sustainable development, which generates employment and income. This aspect corroborates with the research of Moraes et al. (2014) which mentioned that implementing reverse logistics in Brazil enables socioeconomic benefits from the sale of materials, generating employment and income. There is lack of research in the Brazilian reality; moreover, several companies at national level need to comply with the legislation regarding reverse logistics, in order to seek the active participation of the consumer, which is essential for the success of this type of initiative. Based on the research gap, the following research question was developed: Has the implementation of Reverse logistics by the ABINEE's Batteries Collection Program in Brazil resulted in environmental gains in terms of the adequate disposal of hazardous components? Thus, the objective of this article is to evaluate the environmental gains in the implementation of the Reverse Logistics Process by the ABINEE's Battery Collection Program in Brazil.

The ABINEE's Batteries Collection Program consists in the adoption of reverse logistics for portable batteries and batteries for domestic use. This program started in November 2010 in compliance with CONAMA Resolution 401/2008 and NSWP Law 12,305/2010; moreover, it collects used portable batteries all over the national territory as well as, it recycles and disposes the materials properly (Associação Brasileira da Indústria Elétrica e Eletrônica, 2013). Although the first successful stories with reverse logistics contracts are already observed with associations, operators of mobile telecommunications services, retailers, industries and universities - with more than 365 tons of batteries collected, a more comprehensive assessment of environmental assessment is needed (Oliveira, 2013).

This article was subdivided into six sections, the first presents the introduction, followed by a review of the literature on reverse logistics of WEEE, research methodology, results, discussions and conclusions.

\section{Environmental gain of WEEE reverse logistics}

The researches identified environmental gain through the adoption of reverse logistics of WEEE with the use of mathematical simulations in terms of the optimal location of recyclers and manufacturers of electroelectronic products and qualitative data. The "actions" related to the RL, advantages, disadvantages, potential costs and the effectiveness of each proposed action were identified. In addition, the "priority list" of actions was developed 
to be applied in a short, medium and long term, according to Table 1. In short term, the development of public policies regarding the advantages of the adoption of reverse logistics by means of environmental education and control for the society and shareholders awareness becomes highly significant. Thus, the society would assist in the selective collection and the shareholders could adopt reverse logistics for the recycling, reuse and adequate disposal with focus on economic and environmental gains. In medium term, the companies could adopt the design for environment in the product focusing on disassembly and remanufacturing as well as adopt the design for environment in logistics network to identify and establish integration with recyclers with optimum localization to reduce the fuel consumption in transportation process. Thus, it would increase the quantity of recycling, contributing with the reduction of environmental impact. In long term, the use of information technology is suggested, such as RFID, which controls the quantity of recycled materials. In addition, developing carbon credit assessment of companies that adopted reverse logistics for the carbons market is important to highlight.

These actions/strategies are relevant for the Integrated Solid Waste Management (ISWM) and contribute with goals of the "EU 2020 strategy". Digiesi et al. (2015) presented that the ISWM consist in the process of careful and sustained segregation of waste management, focusing on the adoption of waste collection, transportation, recycling and reuse actions. Therefore, it is necessary to use suitable information technology and proper working conditions for employees and establish "social license" among the society, shareholders and politicians. The aim is to reduce the carbon footprint through the installation of collection locations for waste, treatment, recycling and reuse, minimization of emissions in transportation and appropriate disposal in landfills. Achillas et al. (2010a) used the electre and idenfied that in Greece the WEEE reverse logistics is important to meet legislative targets, reducing the possibility of WEEE going to landfills and consequently reducing pollutants from fossil fuels such as $\mathrm{CO}_{2}$ in the atmosphere. Achillas et al. (2010b) developed the linear programming and found the possibility of cost logistics reduction and minimization of emissions of $\mathrm{CO}_{2}$ through the installation of recyclers for the collection and recycling of WEEE in the region of Macedonia. In addition, Achillas et al. (2012) used linear programming and identified the optimum location for the installation of recyclers allows better decision making by business and government managers, minimizing approximately $5 \%$ of $\mathrm{CO}_{2}$ pollutants in the Earth's atmosphere, considering only the analysis of the fuel spent in the process.

In addition, in Turkey was used mathematical simulations in the search for optimal location of recyclers. Aras et al. (2015) implemented linear programming and concluded the opportunity to obtain environmental gain by minimizing the risks of e-waste to landfills. Ayvaz et al. (2015) complements that the application of simulation models in solving stochastic programming problems can demonstrate that it is possible to reduce the pollution in the air and in the environment. Kilic et al. (2015) also used linear programming and mentioned that the study of the simulation scenario presents the best choices of locations for the implantation of recyclers and WEEE storage points, in which twenty-one cities in Turkey relate as favorable. It is pointed out that when applying this configuration to the opportunity of environmental gain through the appropriate disposal of e-waste to landfills.

Other researches carried out in China stressed on the need to implement recycling systems focusing on environmental protection (Tong \& Wang, 2004; Yang et al., 2008). Another one focused on developing ways to collect the waste in urban areas, considering the location that generate more WEEE at the end of their life cycle (Eisenhardt, 1989). A study pointing out that the manufacturer of electronic waste must be able to internally recycle the waste generated in a closed loop was also found (Environmental Protection Agency, 1996a). Another one was found emphasizing that industries and market in general, and especially retailers, should be held accountable for the return of WEEE aimed at recycling (Veenstra et al., 2009). Li \& Tee (2012) adopted the linear programming to assess the integration of the formal and informal waste sectors, identify the opportunity of increase the recycling, and reuse of WEEE and the environmental impact reduction. Lau \& Wang (2009) performed a case study by means of information collected from company web sites, direct observation, and in-depth interviews with four major consumer electronic product manufacturers in China. The result showed that is important the development of environmental laws about reverse logistics for reuse of WEEE. Liu et al. (2016) developed a quality-based price competition model for the WEEE recycling market in a dual channel environment comprising both formal and informal sectors. It was concluded there is lack of control over the formal and informal sectors of WEEE in China, where the accelerated production of electronic equipment and the volume of waste generated in large proportions, lead to serious contamination risks to the environment and the population. In addition, it is known that informal sectors do not use adequate technologies to treat this type of waste, putting workers at risk, as well as lack of control over the proper disposal of e-waste in dumps and landfills (Liu et al., 2016). Thus, the environmental impact can be brought to huge proportions, and considerable damages

The researches developed in Brazil, Araujo et al. (2015) developed the proposal to establish RFID technology in WEEE management by means of mathematical simulation, denoting the relevant opportunity for minimization 


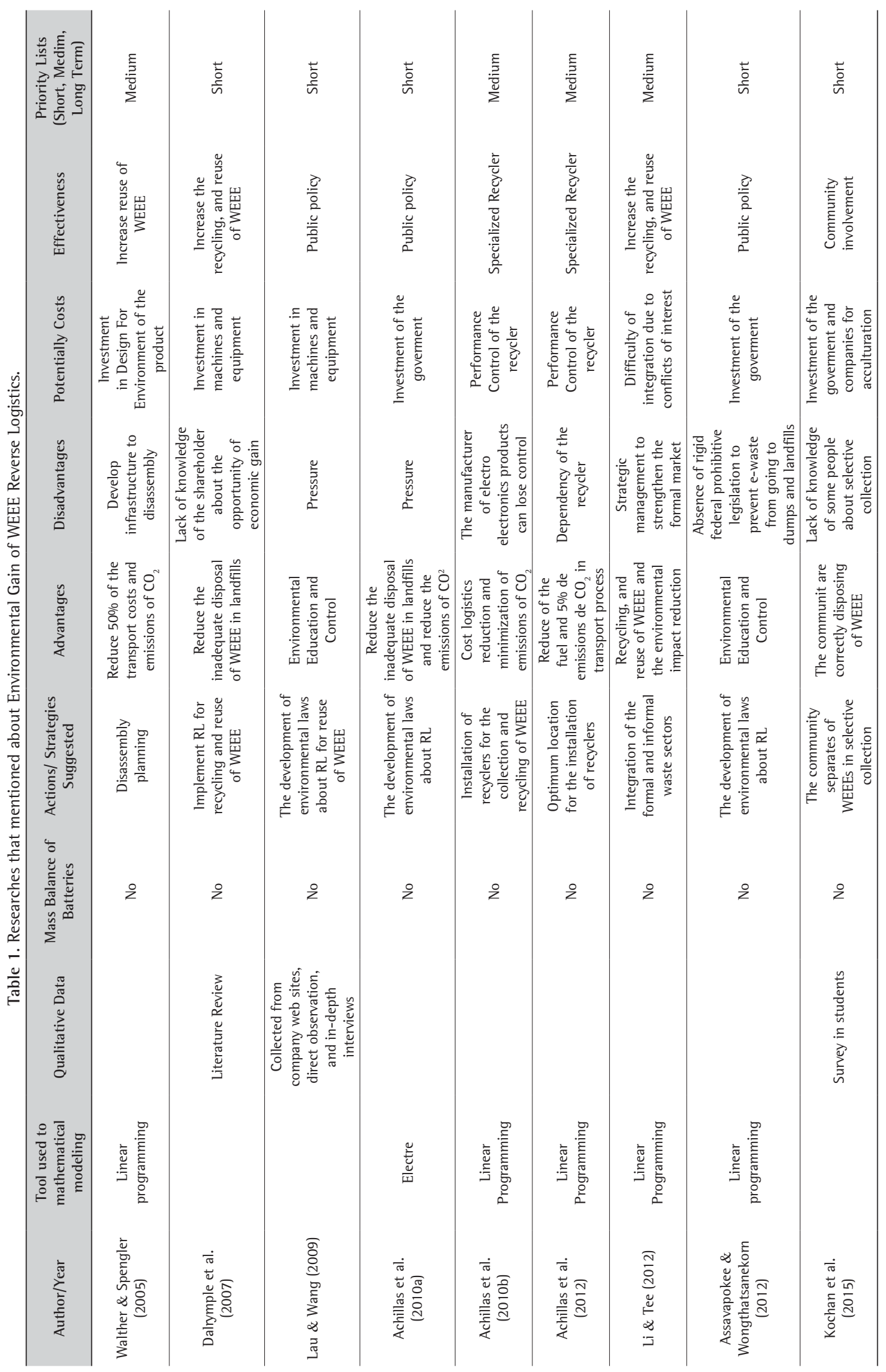



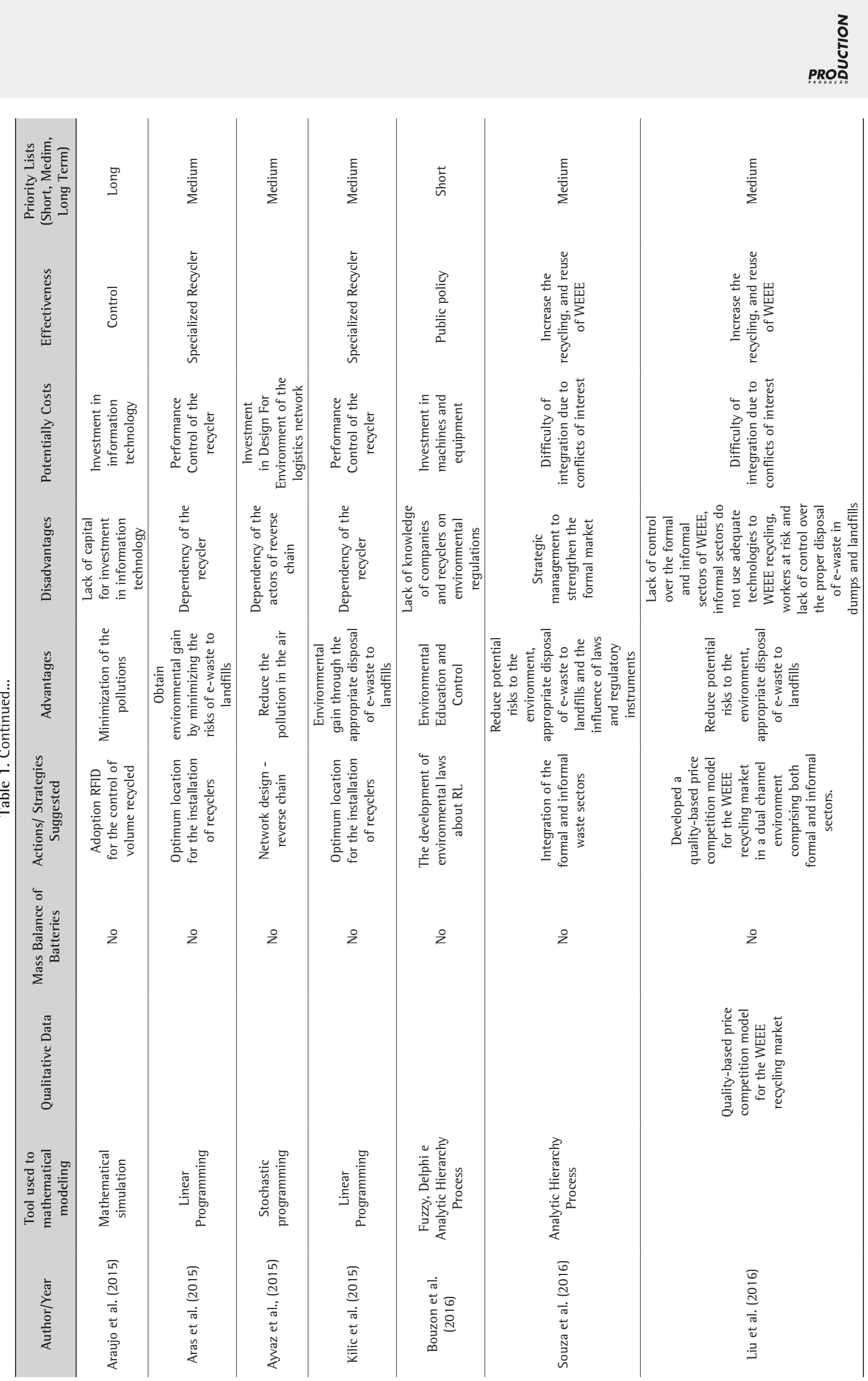





of the pollution. Ghisolf et al. (2017) designed the system dynamics methodology to measure the impact of such legal incentives and the bargaining power obtained by the volume of collected waste on the effective formalization of waste pickers. The results showed the implementation of new recyclers would take more than twenty years. Thus, it suggests requesting tax incentives for structuring. Bouzon et al. (2016) used the tools Fuzy, Delphi e Analytic Hierarchy Process to identify the barriers to adopt of RL in Brazil and found lack of knowledge of companies and recyclers on environmental regulations. Souza et al. (2016) carried out Analytic Hierarchy Process to analysis of the relashionship through formal and informal sectors of WEEE in Brazil, it is important to highlight the representativeness of the informal market and its relevance in the reverse chain. The measurement of this segment involved in informality is an initial step towards the promotion of paths that may reduce potential risks to the environment. In addition, it provides an expanded view of strategic management to strengthen the formal market, avoiding that this type of waste can be directed to dumps and landfills. The influence of laws and regulatory instruments in the current Brazilian reality is also a relevant factor in environmental issues. Foelster et al. (2016) used the life cycle analysis and identify that the refrigerator recycling reduce $720 \mathrm{Kg}$ of $\mathrm{CO}_{2}$.

Other researches carried out in Brazil mentioned qualitative data about the subject. Guarnieri et al. (2016) performed the analysis of reverse logistics of e-waste using strategic options development analysis methodology. The findings present that to increase the adoption of reverse logistics of e-waste in Brazil, is important to teach the concepts of environmental education in schools, companies and trade. In addition, Caiado et al. (2017) carried out specialists analysis about RL carbon credit market, denoting the opportunity to promove the correctly disposal of WEEE. Oliveira Neto et al. (2017) develop the environmental and economic assessment of recycling and reuse of electronic waste in Brazil and Switzerland. The results showed that the Brazilian recyclers need to invest in process of recycling and reuse of printed circuit boards, because with this process the recyclers could extract precious metals for sale increasing the economic gain

Assavapokee \& Wongthatsanekorn (2012) adopted linear programming and identify the absence of rigid federal prohibitive legislation to prevent e-waste from going to dumps and landfills in Texas, USA. A problem that if not treated as a priority, in a long-term basis could cause serious damage to the environment. Kochan et al. (2015) developed the survey in students in the USA and identify that the communit of the Texas are correctly disposing of WEEE. Walther \& Spengler (2005) mentioned that the develop the disassembly planning by means of linear programming to contribute with the WEEE-directive on reverse logistics in Germany. Thus, is possible to reduce $50 \%$ of the transport costs and emissions of $\mathrm{CO}_{2}$ with adoption of RL. The literature review developed by Dalrymple et al. (2007) identified that the WEEE as one of the fastest growing sources of waste in the EU. Thus, is estimated to increase by 16-28 per cent every five years, denoting the importance of develop research and adoption about RL in organizational practice.

Therefore, based on the scientific publications in terms of environmental analysis, it was possible to find references that are mostly qualitative, in which the authors show the negative consequences of pollution by means of fossil fuels and the disposal of e-waste in dumps and landfills, without specifying the type of waste and especially without establishing the mass balance. The quantitative mentions are related to the reduction in percentage of the volume of pollutants derived from $\mathrm{CO}_{2}$, using virtual scenarios and mathematical simulations.

Thereby, in the literature review no article dealing specifically on reverse logistics of portable batteries and batteries for domestic use in Brazil was found. On the other hand, several papers related to e-waste (including batteries) were found in China and Denmark.

The European Directive 2006/66/CE (for reverse logistics of batteries) establishes the extended responsibility to the producer and states that they must implement a collection system for batteries. This Directive lays down minimum collection and recycling targets for the participants, and stipulates that manufacturers must improve the environmental performance of their products reducing continuously the concentration of hazardous substances (European Union, 2003).

Considering the widely disseminated use of batteries in Brazil and the consequent need to educate consumers on the risks to health and the environment resulting from their improper disposal after use, the CONAMA Resolution n. 401/2008 was passed revoking the CONAMA Resolution n. 257/1999. The Resolution n. 401/2008 mentions the need to minimize the negative impacts caused to the environment by improper disposal of batteries, via environmental management, especially of those containing lead, cadmium and mercury in their compositions, in respect to the collection, reuse, recycling, treatment or disposal (Brasil, 2008).

The Brazilian National Solid Waste Policy does not specifically address the solid waste management of e-waste, but points out the need to properly manage solid waste in general. This task includes a number of actions to be undertaken in the stages of collection, transport, transhipment, treatment and environmentally sound disposal of solid waste and environmentally sound disposal of tailings in accordance to the municipal 
plan for integrated solid waste management required under this Law. This management also considers the reverse logistics as an economic and social development tool characterized by a set of actions, procedures and means to ease the collection and recovery of solid waste to the business sector, to reuse in its cycle or other production cycles or other environmentally sound disposal (Brasil, 2010).

According to the NSWP, all stakeholders in the product lifecycle, including manufacturers, importers, distributors and market, consumers and government are responsible for the product at the end of its life cycle. This shared responsibility starts in product design taking into consideration the use of abundant and less polluting raw materials, the production with no use of toxic and hazardous substances, and its aftermarket collection and recycling via reverse logistics (Brasil, 2008). Thus, the adoption of reverse logistics is a way of promoting the collection, recycling and reuse of e-waste. However, the support of the government to enhance environmental education for society and shareholders as well as the clarification of the benefits in adopting reverse logistics should be highlighted (Associação Brasileira da Indústria Elétrica e Eletrônica, 2013).

\section{Metodology}

\subsection{Literature review procedure}

First was developed the search of papers in data bases: Science Direct, Emerald, Taylor \& Francis, Compendex, Scopus, Wiley Library, Scielo and Capes by means of the group of key-words, according Table 2.

Thus, 35 papers were identified. After, the content were analysed of the papers to identify the studies about environmental benefits with adption of WEEE reverse logistics. It were selected 21 works about subject. The 14 papers excluded mention the key words in references or recluse in parts of the manuscript. Thus, the content of the papers was analyzed in terms of: tool used to mathematical modelling, only qualitative data and/or mass balance of batteries, actions/strategies, advantages, disadvantages, potential costs, effectiveness and priority lists (short, medim, long term), according table 1.

Table 2. Group of key-words used for the search of papers in data bases.

\begin{tabular}{l} 
Group of key-words \\
\hline (i) "reverse logistics" And "e-waste" And " recycling"; \\
(ii) "reverse logistics" And "waste electrical and electronic equipment" And " recycling"; \\
(iii) "reverse logistics" And "waste electrical \& electronic equipment" And " recycling"; \\
(iv) "reverse logistics" And "electronic products" And" recycling"; \\
(v) "reverse logistics" And "electro electronic equipment" And " recycling"; \\
(vi) "reverse logistics" And "weee" And " recycling"; \\
(vii) "reverse logistics" And "batteries" And "recycling".
\end{tabular}

\subsection{Data collection procedure}

The data and information were supplemented by primary data obtained from two interviews, a waste management company (ABINEE) and another service provider in reverse logistics (GM\&CLOG). These companies were selected for the research for being pioneers in Brazil. The waste management company (ABINEE) participates in the government commission regarding the sectorial agreement and the GM\&CLOG is the logistics service provider hired by ABINEE for the operation of reverse logistics. After, it was scheduled an interview with the reverse logistics managers. The interview took 4 hours in each company. The managers provided the document with the data of the collections of the batteries per day. Yin (2015) mentions that a case study allows researchers to analyze information obtained in the literature review in the context of the studied environment. This author also comments that interview allows to clarify the object of the study, especially when there is open dialogue with specialists (Seidman, 1991). Regarding this research, interviews with two specialists helped to raise information and data regarding the amount of portable batteries and batteries for domestic use collected annually.

\subsection{Case study methodology}

The research is qualitative and quantitative and it is based on a case study supported by primary and secundary data and information. According to Eisenhardt (1989) a case study is aimed at research practical scenarios envisaging qualitative and quantitative findings. Yin (2015) adds that a case study allows for more realistic understanding of the phenomenon studied in an exploratory manner and emphasizes that the interview is a significant tool for data collection. 


\subsection{Environmental assessment by means of mass balance}

After identifying the amount of batteries, a mass balance was developed to calculate the minimization of environmental impact. Almeida et al. (2006) showed the components (both solid and chemical waste) found in a battery having 35 grams as an average weight. The paper of Almeida et al. (2006) was selected because developed the chemical analysis of the components of the batteries by means of Atomic Absorption Spectrometry (AAS) and the 3052 digestion method. Thus, the methodology used is adequade to develop the mass balance of batteries, according to Almeida et al. (2006).

Table 3 shows the components of solid waste and chemical waste contained in a batterry and their quantities in kilograms and percentages. The solid components are plastic PA - polyamides, metal (steel), brown paper, cardboard, cellophane, anode collector, cathode and anode. Approximately, the chemical waste identified in the solid waste are: Arsenic, Cadmium, Cobalt, Chromium, Copper, Mercury, Potassium, Manganese, Nickel, Lead, Antimony, Silicon, Titanium and Zinc. The chemical elements of higher intensity are Manganese (Mn), with $0.004 \mathrm{~kg}$ per batterry, found in the highest proportion in the cathode, a percentage equal to 98.4\%; and Zinc (Zn), $0.001 \mathrm{~kg}$ per battery was identified equal to $71 \%$ in the anode. A battery also contains low concentrations of Lead $(\mathrm{Pb})$, Mercury $(\mathrm{Hg})$ and Chromium $(\mathrm{Cr})$ that as a whole represent a dangerous set of highly carcinogenic substances.

Table 3. Digestion methods, AAS techniques used to assess batteries components.

\begin{tabular}{|c|c|c|c|}
\hline Description & Components & AAS Technique ${ }^{(1)}$ & Digestion methods ${ }^{(2)}$ \\
\hline $\begin{array}{l}\text { Plastic PA - polyamides, metal } \\
\text { (steel), brown paper, cardboard, } \\
\text { cellophane, anode collector, } \\
\text { cathode and anode }\end{array}$ & & $\begin{array}{l}\text { Weighed in equipament } \\
\text { (mass spectrometer) }\end{array}$ & \\
\hline \multirow{3}{*}{ Anode and cathode } & $\begin{array}{l}\mathrm{Sb}, \mathrm{Cd}, \mathrm{Cr}, \mathrm{Co}, \mathrm{Ni}, \mathrm{Cu}, \mathrm{Pb} \\
\mathrm{Tl}, \mathrm{V}, \mathrm{Zn} \text { e } \mathrm{Mn} \text { in anode }\end{array}$ & $\begin{array}{l}\text { Direct aspiration (Methods } 7040, \\
7130,7190,7200,7210,7420, \\
7520,7840,7910,7950,7460 \\
\text { respectively) }\end{array}$ & $\begin{array}{l}\text { Digestion with nitric acid and } \\
\text { hydrogen peroxide to } 95^{\circ} \mathrm{C} \\
\text { (3050B method) }\end{array}$ \\
\hline & As & Gaseous hydride (7061A method) & \\
\hline & $\mathrm{Hg}$ & $\begin{array}{l}\text { Cold vapor technique } \\
\text { (7470A method) }\end{array}$ & $\begin{array}{c}\text { Digestion in a solution of sulfuric } \\
\text { acid and nitric at } 60{ }^{\circ} \mathrm{C} \\
\text { Permanganate oxidation }\end{array}$ \\
\hline \multirow{2}{*}{ Plastics } & $\begin{array}{l}\mathrm{Sb}, \mathrm{Cd}, \mathrm{Cr}, \mathrm{Co}, \mathrm{Cu}, \\
\mathrm{Pb}, \mathrm{Mn}, \mathrm{Ni}, \mathrm{Tl}, \mathrm{V}, \mathrm{Zn}\end{array}$ & $\begin{array}{l}\text { Direct aspiration (Method } 7040, \\
7130,7190,7200,7210,7420, \\
7460,7520,7840,7910,7950, \\
\text { respectively) }\end{array}$ & $\begin{array}{l}\text { High Pressure 0xidation with } \\
\text { hydrogen peroxide solution } \\
\text { (3052 method) }\end{array}$ \\
\hline & As & Gaseous hydride (7061A method) & $\begin{array}{l}\text { Calcination residue in } 500{ }^{\circ} \mathrm{C} \\
\text { Digestion of ash and oxidation } \\
\text { with concentrated nitric acid } \\
\text { solution }\end{array}$ \\
\hline \multirow[t]{3}{*}{ Other components } & $\begin{array}{c}\mathrm{Sb}, \mathrm{Cd}, \mathrm{Cr}, \mathrm{Co}, \mathrm{Cu}, \mathrm{Pb}, \mathrm{Mn}, \mathrm{Ni} \\
\mathrm{Tl}, \mathrm{V}, \mathrm{Zn}\end{array}$ & $\begin{array}{l}\text { Direct aspiration (method } 7040, \\
\text { 7130, 7190, 7200, 7210,7420, } \\
\text { 7460, 7520, 7840, 7910, 7950, } \\
\text { respectively) }\end{array}$ & $\begin{array}{l}\text { Digestion with nitric acid and } \\
\text { hydrogen peroxide to } 95^{\circ} \mathrm{C} \\
\text { (3050B method) }\end{array}$ \\
\hline & As & Gaseous hydride (7061A method) & \\
\hline & Si (only the cathode collector) & Direct aspiration & Internal method \\
\hline
\end{tabular}

(1)Atomic Absorption Spectrometry (AAS) which consists of testing procedure for the quantitative determination of chemical elements employing the absorption of optical radiation (light) by free atoms in gaseous state (Welz \& Sperling, 1999); ${ }^{(2)}$ The 3052 digestion method is applicable to acid digestion assisted by microwave siliceous matrix and organic matrix and other complex matrices Environmental Protection Agency (1996a); the 3050B method provides two digestion procedures: (i) for the preparation of sediments, sludge, and soil samples for analysis by atomic absorption spectrometry; and (ii) for the preparation of sediment, sludge and soil samples for analysis of samples by Graphite Furnace AA (GFAA) or inductively coupled plasma mass spectrometry (ICP-MS) Environmental Protection Agency (1996b). Source: Adapted based on data from authors Almeida et al. (2006); Secretaria de Estado do Meio Ambiente e Recursos Hídricos (Paraná, 2012); Seidman (1991).

\section{Case study: results}

In the context of the reverse logistics of WEEE in Brazil, the initiatives and situations for this type of waste in terms of post-consumption are illustrated in Figure 1. The process is initiated by the consumer, who is responsible for directing the WEEE to despensation stations, sales channels, municipal collection programs, seasonal programs, voluntary receiving channels and the partial donation of WEEE for reuse when they are reusable. It should be noted that the only flows managed by the manufacturers and importers are comprised of the points of delivery and receipt accredited by them, the formal recyclers, and finally, the industry for the 


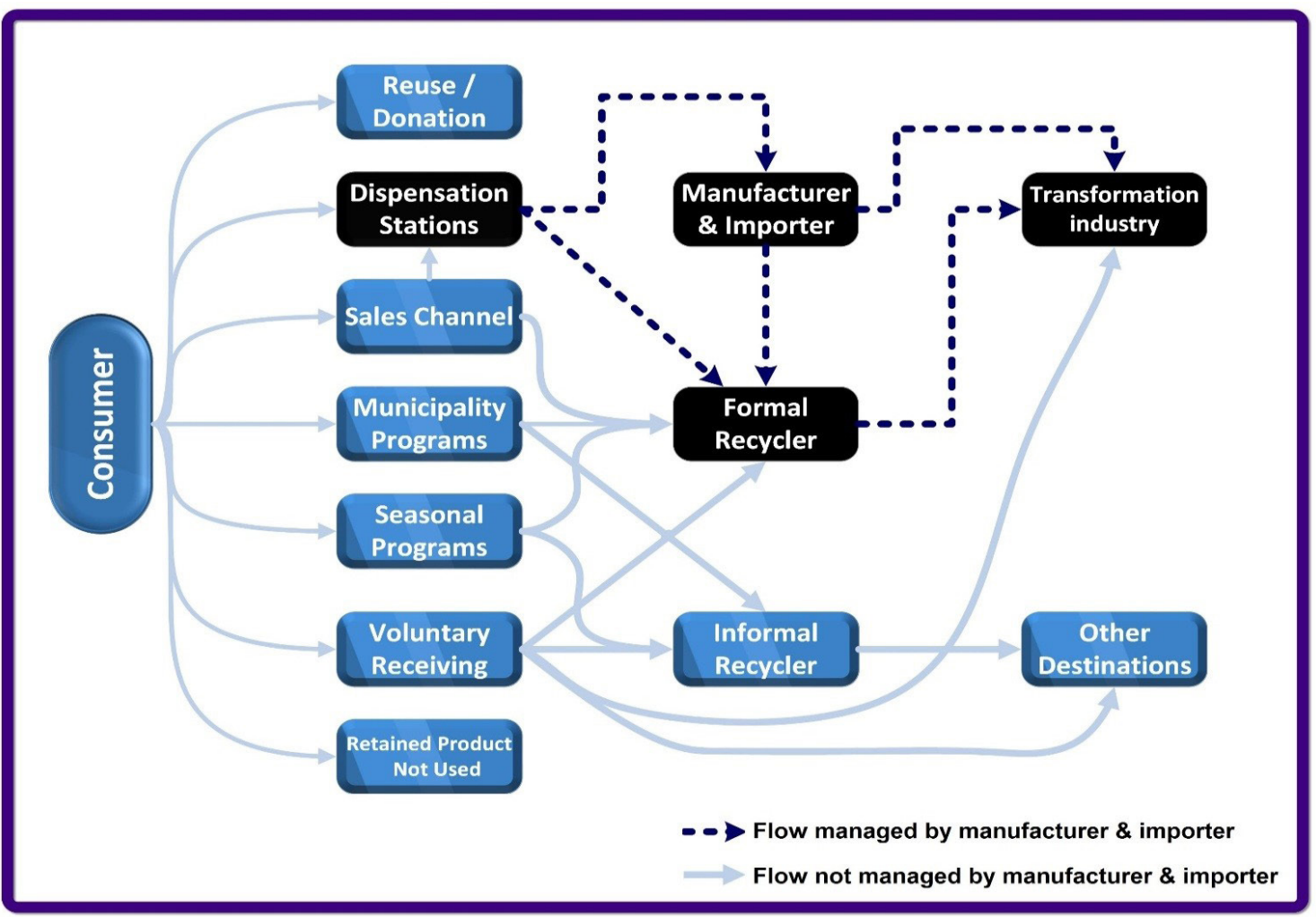

Figure 1. Post-consumption WEEE Reverse Logistics. Source: Authors.

transformation of the WEEE, that makes use of the raw material from the e-waste. It can be perceived the existence of a secondary market, which includes the informal recycler as an active participant in the reverse flow of WEEE, however, not managed by the manufacturers and importers of electronics.

The ABINEE's program is seen as an innovative program in Brazil as it presents to reverse logistics of portable batteries and batteries for domestic use at the national level. This program is underway for about five years and a half and presently is in the process of consolidation in Southern states and expansion in other less developed states countrywide. It encompasses the collection of used batteries returned by consumers nationwide to registered collection ecopoints and its routing through certified carrier. One of this carrier is GM\&CLOG, a company based in São Jose dos Campos, São Paulo State, specialized in transportation, warehousing, reverse manufacturing, sorting and disposal of WEEE (Associação Brasileira da Indústria Elétrica e Eletrônica, 2013). Kilic et al. (2015) emphasizes that reverse logistics is essential for proper WEEE management.

The ABINEE's program provides receipt of batteries returned by consumers and retailers to registered collection points, and its routing through a logistics certified operator. This finding is in accordance with the NSWP which mentions that the manufacturer is not the only responsible for WEEE management, but all the actors involved in this process, including retailers and consumers (Associação Brasileira da Indústria Elétrica e Eletrônica, 2013). Liu et al. (2006) emphasizes the need to provide the means for collecting WEEE in urban areas. Veenstra et al. also reinforces the need of involving retailers in the collection process.

When the waste reaches the storage sites, they are sorted out and the various parts are separated and sent to authorized companies for reuse or recycling. According to Tong \& Wang (2004), the manufacturer must have the capacity to recycle waste internally, but this study shows that there is an option for external recycling by a specialized company. These authors also stresses the importance of reusing or recycling materials as much as possible, this way avoiding disposal in landfills and incineration.

According to Tong \& Wang (2004), reusing or recycling of WEEE contribute to ecosystem protection. Thus, the ABINEE's program is providing an environmentally correct disposal of portable batteries. This action can be seen as an environmental advantage since the componentes of batteries, either solid or liquid (resulting from after use and disposal reactions) are harmful to the environment. 
Figure 2 shows the amount of 4,304,465 alkaline batteries collected through reverse logistics in 2012, considering the sum of the collections in the states. The amount of batteries collected in São Paulo (SP) State in 2012 exceeded by more than three times the amount collected by Rio Grande do Sul (RS) State that stands in the second place. States that collected smaller amounts than this first two were respectively Alagoas (AL), Amazonas (AM), Mato Grosso do Sul (MS), Piauí (PI) and Amapá (AP). Additionally, in Mato Grosso do Sul a more meaningful collection would be expected due to its better economic situation compared with other states. In this regard, it is expected that the extension of the ABINEE's program to that state can be even better structured in terms of collection points than in other states countrywide.



Figure 2. Amount of alkaline batteries (units) disposed correctly in Brazil by state in 2012. Source: Authors.

One way to broaden the scope of the ABINEE's program is the decision to attending specific requests of NGOs, consumers, schools and residential condominiums that are located not far than $50 \mathrm{~km}$ of the states' capitals that are able to gather and store at least a minimum amount of thirty kilos of batteries (Associação Brasileira da Indústria Elétrica e Eletrônica, 2013).

In order to expand the scope of the ABINEE's Program, this Association has signed on January 28, 2012, a Letter of Agreement with the São Paulo State Department of Environment and the Environmental Company of the State of São Paulo (CETESB in Portuguese) in compliance with SMA Resolution 38/2011 (São Paulo, 2012). This resolution provides for actions to be developed in the Project of Support to Municipal Solid Waste Management, provided for in Decree $n^{\circ} 57,817$ (passed in February 28, 2012) which established the State Program for Implementation of Solid Waste Projects.

SMA No. 45 brings the concepts of shared responsibility of the reverse logistics actors, and emphasizes that this system should be implemented independetly of the public system, as highlighted in its Article 2:

These actors are required to design and implement reverse logistics systems by the return of products and packaging after use by the consumer, independently of the public service of urban cleaning and solid waste management, manufacturers, importers, distributors and retailers of products which, by their characteristics, require or may require special systems for packaging, storage, collection, transportation, treatment or disposal, in order to avoid damage to the environment and public health, even after the consumption of these items (São Paulo, 2015).

It is noteworthy that about 30\% of the batteries collected by ABINEE's program are "orphans", which means, they were not produced by the companies participating in the Program. Taking into consideration that the cost to make the environmentally sound disposal of these products is high, these "orphans products" increase the costs of the companies effectively engaged as program members since they take responsibility for the reverse flow of these batteries without any compensation. An additional problem is that these "orphan products" are not following the current legislation as it concerns to the limitations of dangerous substances in their compositions 
imposed by CONAMA Resolution n. 401/2008, this way bringing a potential risk to public health (Associação Brasileira da Indústria Elétrica e Eletrônica, 2013).

Thus, it is important that more manufacturers of batteries sign the sectorial agreement, taking the responsibility with the adoption of reverse logistics, which consequently would increase the quantity of clients of ABINEE. However, for greater efficacy it would be relevant to raise awareness of more manufacturing companies, which represent 30\% of the total. In addition, the government could increase the actions to foster environmental education for the society and companies about environmental and economic benefits with the adoption of reverse logistics, besides promoting financial incentives to reduce taxes. Thus, the shareholders would implement the reverse logistics, increasing the number of manufacturers of batteries and the adhesion of the sectorial agreement, reducing the "orphan products", that negatively affect the effectiveness of the program. The adoption of reverse logistics in Brazil will enable socioeconomic benefits from the sale of materials and the generation of employment and income, according to Moraes et al. (2014).

\subsection{Environmental assessment by means of mass balance}

Table 4 shows the mass balance developed in this study based on the experiment of Almeida et al. (2006) indicating the types and quantities (in $\mathrm{kg}$ ) of solid waste and chemical waste from the batteries that were disposed of correctly via reverse logistics.

Table 4. Total Correct disposal of chemical and solid wastes of the batteries by means of the adoption of reverse logistics in 2012 .

\begin{tabular}{|c|c|c|c|}
\hline Tipes of Solid Wastes & $\begin{array}{l}\text { Solid Waste per Battery (kg), } \\
\text { according to Almeida et al. } \\
\text { (2006) }\end{array}$ & Solid Waste per Battery (\%) & $\begin{array}{c}\text { Total Correct Disposal - Reverse } \\
\text { Logistics by Component (kg) }\end{array}$ \\
\hline Plastic PA - Polyamides & 0.000679 & 1.94 & $2,922.731444$ \\
\hline Metal (steel) & 0.006965 & 19.9 & $29,980.59574$ \\
\hline Brown paper & 0.00016968 & 0.4848 & 730.3815485 \\
\hline Carboard & 0.000095088 & 0.27168 & 409.3029272 \\
\hline Celophane & 0.000071232 & 0.20352 & 306.6156204 \\
\hline Anode collector (brass) & 0.000651 & 1.86 & $2,802.206436$ \\
\hline Cathode & 0.019131 & 54.66 & $82,348.71172$ \\
\hline Anode & 0.0072415 & 20.69 & $31,170.78019$ \\
\hline Sum of the Solid Waste & 0.0350035 & 100.01 & 150,671 \\
\hline $\begin{array}{l}\text { Chemical Waste ldentified in } \\
\text { Solid Waste }\end{array}$ & $\begin{array}{l}\text { Chemical waste per Battery } \\
\text { (kg), according to Almeida et al. } \\
\text { (2006) }\end{array}$ & Chemical waste per Battery (\%) & $\begin{array}{l}\text { Correct disposal - Reverse } \\
\text { Logistics by component }(\mathrm{kg})\end{array}$ \\
\hline Arsenic (As) & 0.0000000063071274 & 0.000089 & 0.027148806 \\
\hline Cadmium (Cd) & 0.000000049740600 & 0.00026 & 0.21410665 \\
\hline Cobalt $(\mathrm{Co})$ & 0.000000285778080 & 0.0036 & 1.230121621 \\
\hline Cromium $(\mathrm{Cr})$ & 0.000002753120160 & 0.04 & 11.85070819 \\
\hline Cupper $(\mathrm{Cu})$ & 0.000083580000000 & 1.2 & 359.7671489 \\
\hline Mercury (Hg) & 0.000000003060960 & 0.000016 & 0.013175794 \\
\hline Potassium (K) & 0.000522276300000 & 2.73 & $2,248.11983$ \\
\hline Manganese (Mn) & 0.004333765129599 & 22.9 & $18,654.53846$ \\
\hline Níckel (Ni) & 0.000019478984112 & 0.28 & 83.846597 \\
\hline Lead $(\mathrm{Pb})$ & 0.000000213122874 & 0.0051 & 0.91737986 \\
\hline Antimony (Sb) & 0.000000132335000 & 0.0019 & 0.569631319 \\
\hline Silicon (Si) & 0.000000250740000 & 0.0036 & 1.079301447 \\
\hline Titanium (Ti) & 0.000000760981200 & 0.006 & 3.275616615 \\
\hline Zinc (Zn) & 0.001018760988308 & 14.5 & $4,385.220581$ \\
\hline Sum of Chemical Waste & 0.005982317 & 41.67057 & 25,751 \\
\hline
\end{tabular}

Source: Authors.

The results show that the implementation of reverse logistics of the ABINEE's program has generated environmental advantages via proper disposal (recycling) of both solid and chemical waste. That way, it generated a reduction in the dump into the environment of $150,671 \mathrm{~kg}$ of solid waste, especially the cathode $(82,348.71 \mathrm{~kg})$ and $29,980.59 \mathrm{~kg}$ of steel that surrounds the batteries. This result contributes to the scientific literature as it regards to measuring environmental advantages coming from reverse logistics of batteries. 
Due to several hazardous components, chemical waste is the most harmful to human health. Table 3 shows that $25,751 \mathrm{~kg}$ of these components, including mercury, lead and arsenic, which are carcinogens, that cannot to be improperly released in the environment.

Table 4 also shows up that the reverse logistics of 4,304,465 batteries contributed to proper disposal of $150,671 \mathrm{~kg}$ of solid waste and 25,751 kg of chemical waste in the environment, totaling 176,422 kg in 2012.

As sectoral agreements recommended by the NSWP begins to signed, involving a number of actors of productive chains, it is expected that Brazil create conditions to better address the issue of its waste management, helping to change the consumer's perceptions, which will be crucial for the success of the planned reverse logistics practices. One of the items to be included in the proposals for sectoral agreements is a communication plan to divulge and work on public awareness. Another prediction of the sectoral agreement is the need to introduce targets to be met by the reverse logistic programs, both geographical goals (coverage) and the minimum amounts to be collected, contributing to reducing the environmental impact of those products.

\section{Discussion}

The implementation of reverse logistics for batteries in Brazil resulted in reduction of pollution in the environment, around 150,671 kg of solid waste and 25,751 kg of chemical waste in the environment, totaling $176,422 \mathrm{~kg}$ in 2012 . These findings were counted through the mass balance, denoting contribution to the organizational practice and scientific literature. In terms of contribution to the scientific literature it includes the evaluation of the environmental gains from the adoption of reverse logistics of batteries, especially when considering hazardous chemical residues, which are carcinogenic to the health of society by accounting for mass balance using digestion methods, AAS techniques used to assess batteries components, as pointed out by Almeida et al. (2006). Thus, this research shows a different attribute of the existing research on the subject, because no research developed the mass balance of batteries to account for the environmental gain, resulting from reverse logistics in the Brazilian scenario.

Thus, the results of this research also contribute to the organizational practice, since several companies at the national level are already structuring to comply with the legislation regarding reverse logistics, seeking consumer's active participation, which is essential for the success of this kind of initiative. With the mass calculation application, it is possible for the entrepreneur to develop performance indicators with goals, aiming for continuous improvements. The results of the performance indicators are important for good communication with the public in terms of environmental actions, making it possible to build an environmental corporate image, which is in the genesis of recyclers.

In addition, the qualitative and quantitative analysis of the reverse logistics of batteries carried out in this study taking as a reference the ABINEE's program allow some general considerations concerning the challenges of deployment and implementation of reverse logistics actions. The reverse logistics of batteries (among others WEEE), as called for in the NSWP, is an important tool for economic and social development. However, considering that this policy is still in its infancy, various problems are emerging as potential barriers to its implementation especially as it concerns to extending the scope of these reverse logistics programs among the actors of the recycling network.

It is important to emphasize that most companies that place batteries on the market are importers and only a few of them have joined the ABINEE's program. Therefore, companies that have not joined this iniative are acting irresponsibly, this way posing obstacles to the expansion of the program and also creating a commercial disadvantage to other companies that bear the costs of collection and recycling of batteries placed on the market. This situation leads to poor supervision by the authorities and lack of punishment to those that are not meeting the law.

A higher performance of Brazilian Institute of Environment and Renewable Natural Resources (IBAMA in Portuguese) and National Institute of Metrology, Quality and Technology (INMETRO in Portuguese) in the inspection of these products at the time of import, similarly to the agreement signed with lamps, can be a crucial factor for the program regarding the participation of a greater share of importers in this market.

Another point to be highlighed is that retailing companies also has to play role in this supply chain and comply with legal requirements. As described in CONAMA's Resolution n. 401/08 (Brasil, 2008) and NSWP (Brasil, 2010), market has the obligation to receive the batteries. This result corroborates the research of Souza et al. (2016) in relation to the influence of laws and regulatory instruments in the current brazilian reality. It is also a relevant factor in environmental issues and other researches around the world that mention the importance of electronics manufacturing companies to implement the reverse logistics of WEEE to comply with legislation, aiming to minimize landfill contamination in Greece (Achillas et al., 2010a) and China (Liu et al., 2016), which 
indicates the need to improve regulatory control. Assavapokee \& Wongthatsanekorn (2012) also mentions the absence of rigid federal prohibitive legislation that would prevent e-waste from going to dumps and landfills in Texas, USA.

Thus, if they joined the ABINEE's program they would not only help to extend the scope of this iniciative, but also provide new collection points easing the disposal of the WEEE by population. The above mentioned problems are challlenges to be overcame in the coming years and, to some extent, they are responsible for the relatively insignificant amount of batteries collected via the ABINEE's Program all over the country. Thus, it was identified the collection of the 4,304,465 batteries by means of adoption of WEEE reverse logistics, resulting in proper disposal of 176,422 $\mathrm{kg}$ of solid and chemical waste. The dismantling of such batteries revealed that the cathode component is the solid waste with greater mass and Manganese $(\mathrm{Mn})$ is the most significant chemical waste in quantitative terms.

According to one of ABINEE's director, lately there has been an increasing demand for information on how consumers, businesses and governments can take part of the ABINEE's initiative and also on how to expand the amount of collection points throughout the country. From one side, this indicates that people seems to be becoming more aware of the importance of adequately disposing of WEEE and from the other side, it shows that the ABINEE's program is positively influencing people's behavior as concerns reverse logistics practices of batteries at country level. This finding indicated that the ABINEE is able to conduct the operation of reverse logistics of batteries in Brazil; however, the efficacy could be improved with increasing participation of the companies in the sectorial agreement, minimizing the "orphans products". Thus, Digiesi et al. (2015) stated that is important the adoption of WEEE reverse logistics for the ISWM, aiming the development of more collection points for the recycling and adequate waste disposal; moreover, it was suggested to establish the "social license" among society, shareholders and politicians to work together on minimizing the carbon footprint.

\section{Conclusion}

The adoption of reverse logistics allowed the collection of 4,304,465 post consumed batteries, resulting in the minimization of environmental impact in $150,671 \mathrm{~kg}$ of solid waste and $25,751 \mathrm{~kg}$ of chemical waste. Thus, this research contributed to the mass balance measurement of hazardous components in batteries, as well as evidenced that reverse logistics of batteries can reduce the environmental impact.

In addition, this research also stimulated corporate practices to improve the environmental image of electronic product manufactures when decreasing the environmental impact. This fact encourages other electronic manufactures to establish a sectorial agreement for the adoption of WEEE reverse logistics, resulting in new employment opportunities and incomes. Other relevant aspect consists in the reverse chain development, considering the integrated solid waste management through the participation of waste management companies, service providers in reverse logistics, recyclers and incineration companies.

Then, a substantial number of actions can be proposed to overcome barriers to the ABINEE's program implementation in a medium and long term. First, a greater commitment from government in ABINEE's Program is required in various states to increase the collection of batteries in retailers, drug stores, gas stations, schools and government offices, as well as to ensure their transportation. The public and private sectors could promote campaigns for enhancing awareness about the risks of improper disposal of batteries.

A limitation of this research is that the case study was conducted at only one waste management company and one service provider of reverse logistics of batteries located in Brazil, with a particular reverse chain process. Further research is recommended for other reverse chain processes in Brazil or in different countries to provide more conclusions in order to reinforce the findings presented here. In addition, it is suggested the adoption of ISWM in reverse logistics process proposed by Digiesi et al. (2015) because play a crucial role for the future of the Solid Waste Policy under environmental perspective. The ISWM consists in an interesting and innovative strategy for support the decisions of the public administration in order to reduce, in medium-long time, the solid waste, improve the waste management by adoption of cyber systems, and increase the public and private participation in reverse chain development.

\section{References}

Achillas, Ch., Aidonis, D., Vlachokostas, Ch., Moussiopoulos, N., Banias, G., \& Triantafillou, D. (2012). A multi-objective decision-making model to select waste electrical and electronic equipment transportation media. Resources, Conservation and Recycling, 66, 76-84. http://dx.doi.org/10.1016/j.resconrec.2012.01.004. 
Achillas, Ch., Vlachokostas, Ch., Moussiopoulos, N., \& Banias, G. (2010a). Decision support system for the optimal location of electrical and electronic waste treatment plants: a cesse study in Greece. Waste Management, 30(5), 870-879. http://dx.doi.org/10.1016/j. wasman.2009.11.029. PMid:20031385.

Achillas, Ch., Vlachokostas, Ch., Aidonis, D., Moussiopoulos, N., lakovou, E., \& Banias, G. (2010b). Optimizing reverse logistics network to support policy-making in the case of Electrical and Electronic Equipment. Waste Management, 30(12), 2592-2600. http://dx.doi. org/10.1016/j.wasman.2010.06.022. PMid:20696562.

Almeida, M. F., Xará, S. M., Delgado, J., \& Costa, C. A. (2006). Caracterization of spent AA holsehold alcaline batteries. Waste Management, 26(5), 466-476. http://dx.doi.org/10.1016/j.wasman.2005.04.005. PMid:15964181.

Aras, N., Korugan, A., Buyukozkan, G., Serifoglu, F. S., Erol, 1., \& Velioglu, M. N. (2015). Locating recycling facilities for IT-based electronic waste in Turkey. Journal of Cleaner Production, 105, 324-336. http://dx.doi.org/10.1016/j.jclepro.2015.02.046.

Araujo, M. V. F., Oliveira, U. R., Marins, F. A. S., \& Muniz Junior, J. (2015). Cost assessment and benefits of using RFID in reverse logistics of waste electrical and electronic equipment (WEEE). Procedia Computer Science, 55(6), 688-697. http://dx.doi.org/10.1016/j. procs.2015.07.075.

Assavapokee, T., \& Wongthatsanekorn, W. (2012). Reverse production system infrastructure design for electronic products in the state of Texas. Computers \& Industrial Engineering, 62(1), 129-140. http://dx.doi.org/10.1016/j.cie.2011.09.001.

Associação Brasileira da Indústria Elétrica e Eletrônica. (2013). Programa ABINEE Recebe Pilhas: mais de 400 toneladas em quase 3 anos. São Paulo: ABINEE. Retrieved in 2017, August 7, from http://www.abinee.org.br/notícias/com28.htm

Ayvaz, B., Bolat, B., \& Aydin, N. (2015). Stochastic reverse logistics network design for waste of electrical and electronic equipment. Resources, Conservation and Recycling, 104, 391-404. http://dx.doi.org/10.1016/j.resconrec.2015.07.006.

Bouzon, M., Govindan, K., Rodriguez, C., \& Campos, L. (2016). Identification and analysis of reverse logistics barriers using fuzzy Delphi method and AHP. Resources, Conservation and Recycling, 108, 182-197. http://dx.doi.org/10.1016/j.resconrec.2015.05.021.

Brasil, Ministério do Meio Ambiente, Conselho Nacional do Meio Ambiente. (2008, November 5). Estabelece os limites máximos de chumbo, cádmio e mercúrio para pilhas e baterias comercializadas no território nacional e os critérios e padrões para o seu gerenciamento ambientalmente adequado, e dá outras providências (Resolução CONAMA $n^{\circ} 401$, de 04 de novembro de 2008). Diário 0ficial da República Federativa do Brasil.

Brasil. (2010, August 3). Institui a Política Nacional de Resíduos Sólidos; altera a Lei $n^{\circ}$ 9.605, de 12 de fevereiro de 1998; e de outras providências (Lei $n^{\circ}$ 12.305, de 2 de agosto de 2010). Diário Oficial da República Federativa do Brasil.

Caiado, N., Guarnieri, P., Xavier, L. H., \& Chaves, G. L. D. (2017). A characterization of the Brazilian market of reverse logistic credit (RLC) and an analogy with the existing carbon credit market. Resources, Conservation and Recycling, 118(7), 47-59. http://dx.doi. org/10.1016/j.resconrec.2016.11.021.

Dalrymple, 1., Wright, N., Kellner, R., Bains, N., Geraghty, K., Goosey, M., \& Lightfoot, L. (2007). An integrated approach to electronic waste (WEEE) recycling. Circuit World, 33(2), 52-58. http://dx.doi.org/10.1108/03056120710750256.

Digiesi, S., Facchini, F., Mossa, G., Mummolo, G., \& Verriello, R. (2015). A cyber - based dss for a low carbon integrated waste management system in a smart city. IFAC-PapersOnLine, 48(3), 2356-2361. http://dx.doi.org/10.1016/j.ifacol.2015.06.440.

Eisenhardt, K. M. (1989). Building theories from case study research. Academy of Management Review, 14(4), 532-550. http://dx.doi. org/10.5465/amr.1989.4308385.

Environmental Protection Agency. (1996a). Method 3050B: acid digestion of sediments, sludges and soils. Washington: EPA. Retrieved in 2017, August 7, from http://www.epa.gov/osw/hazard/testmethods/sw846/pdfs/3050b.pdf

Environmental Protection Agency. (1996b). Method 3052: microwave assisted acid digestion of siliceous and organically based matrices, SW-846. Washington: EPA. Retrieved in 2017, August 7, from http://www.epa.gov/osw/hazard/testmethods/sw846/pdfs/3052.pdf

European Union. (2003, February 13). Parlamento Europeu e do Conselho, de 27 de janeiro de 2003, relativa aos resíduos de equipamentos eléctricos e electrónicos (REEE) (Directiva 2002/96/CE). Official Journal of the European Union. Retrieved in 2017, August 7, from http://eur-lex.europa.eu

Foelster, A.-S., Andrew, S., Kroeger, L., Bohr, P., Dettmer, T., Boehme, S., \& Herrmann, C. (2016). Electronics recycling as an energy efficiency measure e a Life Cycle Assessment (LCA) study on refrigerator recycling in Brazil. Journal of Cleaner Production, 129, 30-42. http://dx.doi.org/10.1016/j.jclepro.2016.04.126.

Ghisolf, V., Chaves, G., Siman, R., \& Xavier, L. (2017). System dynamics applied to closed loop supply chains of desktops and laptops in Brazil: a perspective for social inclusion of waste pickers. Waste Management, 60, 14-31. http://dx.doi.org/10.1016/j. wasman.2016.12.018. PMid:28034614.

Guarnieri, P., e Silva, L. C., \& Levino, N. A. (2016). Analysis of electronic waste reverse logistics decisions using Strategic Options Development Analysis methodology: a Brazilian case. Journal of Cleaner Production, 133, 1105-1117. http://dx.doi.org/10.1016/j. jclepro.2016.06.025.

Kilic, H. S., Cebeci, U., \& Ayhan, M. B. (2015). Reverse logistics system design for the waste of electrical and electronic equipment (WEEE) in Turkey. Resources, Conservation and Recycling, 95, 120-132. http://dx.doi.org/10.1016/j.resconrec.2014.12.010.

Kochan, C. G., Pourreza, S., \& Tran, H. (2015). Determinants and logistics of e-waste recycling. International Journal of Logistics Management, 27(10), 52-70.

Lau, K. H., \& Wang, Y. (2009). Reverse logistics in the electronic industry of China: a case study. Supply Chain Management: An International Journal, 14(11), 447-465.

Leite, P. R. (2009). Logística reversa: meio ambiente e competitividade. São Paulo: Pearson Prentice Hall.

Li, R. C., \& Tee, T. J. C. (2012). A reverse logistics model for recovery options of e-waste considering the integration of the formal and informal waste sectors. Procedia: Social and Behavioral Sciences, 40(9), 788-816. http://dx.doi.org/10.1016/j.sbspro.2012.03.266.

Liu, H., Lei, M., Deng, H., Keong Leong, G., \& Huang, T. (2016). A dual channel, quality-based price competition model for the WEEE recycling market with government subsidy. Omega, 59, 290-302. http://dx.doi.org/10.1016/j.omega.2015.07.002.

Liu, X., Tanaka, M., \& Matsui, Y. (2006). Electrical and electronic waste management in China: progressand the barriers to overcome. Waste Management \& Research, 24(1), 92-101. http://dx.doi.org/10.1177/0734242X06062499. PMid:16496875. 
Lucato, W. C., Costa, E. M., \& Oliveira Neto, G. C. (2017). The environmental performance of SMEs in the Brazilian textile industry and the relationship with their financial performance. Journal of Environmental Management, 203(Pt 1), 550-556. http://dx.doi. org/10.1016/j.jenvman.2017.06.028. PMid:28647218.

Moraes, D. G. S. V. M., Rocha, T. B., \& Ewald, M. R. (2014). Life cycle assessment of cell phones in Brazil based on two reverse logistics scenarios. Production, 24(4), 735-741. http://dx.doi.org/10.1590/S0103-65132014005000011.

Oliveira Neto, G. C., \& Lucato, W. C. (2016). Production planning and control as a tool for eco-efficiency improvement and environmental impact reduction. Production Planning and Control, 27(3), 148-156. http://dx.doi.org/10.1080/09537287.2015.1089605.

Oliveira Neto, G. C., Correia, A. J. C., \& Schroeder, A. M. (2017). Economic and environmental assessment of recycling and reuse of electronic waste: multiple case studies in Brazil and Switzerland. Resources, Conservation and Recycling, 127, 42-55. http://dx.doi. org/10.1016/j.resconrec.2017.08.011.

Oliveira, M. (2013). Solução completa em logística reversa e reciclagem de eletroeletrônicos. In Anais do $4^{\circ}$ Forum Internacional de Resíduos Sólidos. São Paulo: CLRB. Palestra proferida na sessão case das empresas GM\&CLOG Logística, Umicore Brasil e Nextel Telecomunicações.

Paoli, F. M., Oliveira Neto, G. C., \& Lucato, W. C. (2013). Economic and environmental gains resulting from the utilization of the design for the environment (DfE). Espacios, 34(12), 1-11.

Paraná, Secretaria de Estado do Meio Ambiente e Recursos Hídricos. (2012, August 9). Edital de Chamamento para Apresentação de Termos de Compromisso para implantação de Sistemas de Logística Reversa para fins de recolhimento, tratamento e destinação final de resíduos sólidos (Edital de Chamamento no 01/2012, de 09 de agosto de 2012). Diário Oficial do Estado do Curitiba.

Rogers, D. S., \& Tibben-Lembke, R. S. (1998). Going backwards: reverse logistics trends and practices. Reno: Reverse Logistics Executive Council.

São Paulo, Secretaria de Estado do Meio Ambiente. (2012, June 6). Dispõe sobre ações a serem desenvolvidas no Projeto de Apoio à Gestão Municipal de Resíduos Sólidos, previsto no Decreto $n^{\circ}$. 57.817, de 28 de fevereiro de 2012, que instituiu o Programa Estadual de Implementação de Projetos de Resíduos Sólidos (Resolução SMA no 38, de 5 de junho de 2012). Diário Oficial do Estado.

São Paulo, Secretaria de Estado do Meio Ambiente. (2015, June 24). Define as diretrizes para implementação e operacionalização da responsabilidade pós-consumo no Estado de São Paulo, e dá providências correlatas (Resolução SMA no 45, de 23 de junho de 2015). Diário Oficial do Estado.

Seidman, 1. E. (1991). Interviewing as qualitative research: a guide for researchers in education and the social sciences. New York: Teachers College.

Souza, R., Clímaco, J., Sant'ana, A., Rocha, T., Valle, R., \& Quelhas, O. (2016). Sustainability assessment and prioritisation of e-waste management options in Brazil. Waste Management, 57, 46-56. http://dx.doi.org/10.1016/j.wasman.2016.01.034. PMid:26852754

Tong, X., \& Wang, J. (2004). Transnational flows of e-waste and spatial patterns of recycling in China. Eurasian Geography and Economics, 45(8), 608-621. http://dx.doi.org/10.2747/1538-7216.45.8.608.

Veenstra, A., Wang, C., Fan, W., \& Ru, Y. (2009). Analysis of e-waste flows in China. International Journal of Advanced Manufacturing Technology, 47(5-8), 449-459.

Walther, G., \& Spengler, T. (2005). Impact of WEEE-directive on reverse logistics in Germany. International Journal of Physical Distribution \& Logistics Management, 35(5), 337-361. http://dx.doi.org/10.1108/09600030510607337.

Welz, B., \& Sperling, M. (1999). Atomic absorption spectrometry. Weinheim, Germany: Wiley-VCH

Yang, J., Lu, B., \& Xu, C. (2008). WEEE flow and mitigating measures in China. Waste Management, 28(9), 1589-1597. http://dx.doi. org/10.1016/j.wasman.2007.08.019. PMid:17935966.

Yin, R. K. (2015). Estudo de caso: planejamento e métodos. São Paulo: Bookman. 